RAMIRES, Celso Costa; ROCHA NETO, Odir Gomes da. A reforma dos Tribunais de Contas: uma revisão a partir das propostas de emendas constitucionais. Revista Eletrônica Direito e Política, Programa de Pós-Graduação Stricto Sensu em Ciência Jurídica da UNIVALI, Itajaí, v.10, n.2, 10 quadrimestre de 2015. Disponível em: www.univali.br/direitoepolitica - ISSN 1980-7791.

\title{
A REFORMA DOS TRIBUNAIS DE CONTAS: UMA REVISÃO A PARTIR DAS PROPOSTAS DE EMENDAS CONSTITUCIONAIS
}

\author{
REFORM OF THE COURT OF ACCOUNT: A REVIEW ON THE BASIS OF \\ CONSTITUTIONAL AMENDMENTS PROPOSED
}

Celso Costa Ramires ${ }^{1}$

Odir Gomes da Rocha Neto ${ }^{2}$

SUMÁRIO: Introdução; 1. Declaração de Lima sobre as Linhas Básicas da Fiscalização; 2. Modelos de controle externo; 3. Tribunais de Contas e Controle Externo; 4. Reformas dos Tribunais de Contas; 4.1 Modelo de Controle Externo; 4.2 Controles administrativos dos Tribunais de Contas; 4.3Composição das Cortes de Contas; 4.4 Hierarquia entre as Cortes de Contas; Considerações Finais; Referências das Fontes Citadas.

RESUMO: Na medida em que a sociedade anseia a boa governança pública, com a prestação de serviços públicos eficientes, cresce a discussão sobre a atuação dos Tribunais de Contas no Brasil. O presente artigo analisa as propostas de emendas constitucionais entre os anos de 2007 e 2013, que buscam alterar aspectos da fiscalização pública externa, com foco na modificação do modelo de controle externo, na mudança da composição dos órgãos de controle externo e na criação de controle administrativo das Cortes de Contas. Tais propostas debatem a autonomia das Cortes de Contas em relação aos Poderes do Estado, bem como a separação entre o Corpo Deliberativo e o quadro técnico. Assim, o estudo constatou que as propostas dos congressistas procuram aprimorar o controle externo no Brasil de maneiras diferentes. Ora prevendo a criação da Auditoria-Geral em substituição aos Tribunais de Contas, ora fortalecendo o atual modelo de controle com a criação do Conselho Nacional dos Tribunais de Contas,

\footnotetext{
${ }^{1}$ Mestrando em Ciência Jurídica pela Universidade do Vale do Itajaí - UNIVALI - SC. Especialista em Direito Constitucional pela Faculdade de Direito Damásio de Jesus - FDDJ - SC. Auditor Fiscal de Controle Externo do Tribunal de Contas do Estado de SC. e-mail: celso@tce.sc.gov.br.

${ }^{2}$ Mestrando em Ciência Jurídica pela Universidade do Vale do Itajaí - UNIVALI - SC. Especialista em Estudos Estratégicos em Administração Pública pela Universidade do Estado de Santa Catarina (UDESC), Auditor Fiscal de Controle Externo do Tribunal de Contas do Estado de SC. email: ogrneto@gmail.com.
} 
RAMIRES, Celso Costa; ROCHA NETO, Odir Gomes da. A reforma dos Tribunais de Contas: uma revisão a partir das propostas de emendas constitucionais. Revista Eletrônica Direito e Política, Programa de Pós-Graduação Stricto Sensu em Ciência Jurídica da UNIVALI, Itajaí, v.10, n.2, 10 quadrimestre de 2015. Disponível em: www.univali.br/direitoepolitica - ISSN 1980-7791.

ora modificando a forma de designação e exoneração dos ministros e conselheiros.

Palavras-chave: Tribunais de Contas, controle externo, controle administrativo.

ABSTRACT: As the company looks forward to good public governance, with the provision of efficient public services, growing discussion about the performance of audit offices in Brazil. From the game theory of metaphor, this article analyzes proposals for constitutional amendments between the years 2007 and 2013, seeking to change aspects of external public supervision, focusing on the change in the external control model, changing the composition of organs of external control and the creation of administrative control of the Court of Cortes. Such proposals discuss the autonomy and independence of the Court of Cortes with the branches of government and between the Deliberative Body and the technical. Thus, the study ascertained that the proposals of the congressmen seek to enhance the external control in Brazil in different ways. Sometimes providing for the establishment of the Auditor General to replace the Account Courts, sometimes strengthening the current control model with the creation of the National Council of Account Courts, sometimes changing the form of appointment and dismissal of ministers and advisers.

Keywords: Audit Courts, external control, administrative control.

\section{INTRODUÇÃO}

Muito se tem discutido sobre o modelo de controle externo brasileiro, precipuamente sobre a atuação dos Tribunais de Contas. As manifestações de junho de 2013 mostraram o desejo da população na melhoria do transporte público, da educação e da saúde, o aperfeiçoamento do combate à corrupção, enfim, a boa governança pública.

O Jornal do Brasil, em dezembro de 2013, publicou retrospectiva explicando que tais manifestações começaram como protesto ao aumento da tarifa de ônibus, para depois abranger temas como "corrupção política, má qualidade dos serviços públicos $^{\prime \prime}{ }^{3}$, gastos públicos com a copa e olimpíadas, além de outros temas.

\footnotetext{
${ }^{3}$ FREITAS, Cláudia. Retrospectiva - Manifestações de junho agitaram todo o país: Protestos nas ruas abrangeram os mais variados temas. Jornal do Brasil. Rio de Janeiro. 17 dez. 2013. Disponível em: <http://www.jb.com.br/retrospectiva-2013/noticias/2013/12/17/retrospectivamanifestacoes-de-junho-agitaram-todo-o-pais/>. Acesso em: 09 mar. 2015.
} 
RAMIRES, Celso Costa; ROCHA NETO, Odir Gomes da. A reforma dos Tribunais de Contas: uma revisão a partir das propostas de emendas constitucionais. Revista Eletrônica Direito e Política, Programa de Pós-Graduação Stricto Sensu em Ciência Jurídica da UNIVALI, Itajaí, v.10, n.2, 10 quadrimestre de 2015. Disponível em: www.univali.br/direitoepolitica - ISSN 1980-7791.

Já o Portal de notícias G1 lançou o infográfico "Resultados das manifestações de junho"4, onde mostra o resultado de pesquisa realizada pelo Instituto Brasileiro de Opinião Pública e Estatística (IBOPE) em que 2002 pessoas responderam três motivos pelos quais elas foram às ruas. Em primeiro lugar, encontrava-se o transporte público com 53,7\% dos respondentes. Em seguida, vinham os seguintes motivos: contra à corrupção (49\%); redução da tarifa (40,5\%); saúde $(36,7 \%)$; gastos com copa/copa das confederações $(30,9 \%)$; educação $(29,8)$, entre outros.

Inexoravelmente, tais anseios perpassam pelo controle externo realizado pelas Cortes de Contas que, por meio de suas atividades fiscalizatórias podem contribuir para a satisfação dos direitos sociais e com a detecção dos casos de corrupção e desvios, constituindo-se em meios de garantias administrativas nas palavras de Pisarello. ${ }^{5}$

O presente artigo detalha as diversas propostas de emendas constitucionais que procuram alterar as Cortes de Contas federal e subnacionais. Para tanto, foram selecionados elementos estruturantes a partir dos quais se realizou a pesquisa documental nas propostas legislativas produzidas entre os anos de 2007 e 2013, quais sejam: o modelo de controle externo; o controle administrativo dos Tribunais de Contas; a composição das Cortes de Contas; a hierarquia entre as Cortes de Contas.

Assim, buscou-se neste artigo, avaliar as emendas constitucionais propostas para modificar a estrutura dos Tribunais de Contas. Não se trata de uma reflexão definitiva ou propositiva, mas de uma análise condensada e orientada para se aglutinar os principais pontos de discussão sobre as Cortes de Contas, as quais alterarão as regras do jogo processual administrativo, precipuamente, modificando a posição dos julgadores (Ministros e Conselheiros) e atores

\footnotetext{
${ }^{4}$ MORENO, Ana Carolina. Resultado das manifestações de junho: Veja quais foram as principais demandas, a linha do tempo dos protestos e como os poderes reagiram a eles. Portal de notícias G1. Edição: Leo Aragão (Arte) e Gustavo Miller (Conteúdo). Design: Dalton Soares, Daniel Roda e Elvis Martuchelli. Desenvolvedores: Rafael Soares e Thiago Bittencourt. Rio de Janeiro, 28 jun. 2013. Disponível em: <http://g1.globo.com/brasil/linha-tempo-manifestacoes-2013/platb/>. Acesso em: 09 mar. 2015.
}

${ }^{5}$ PISARELLO, Gerardo. Los derechos sociales y sus garantías. Madrid: Trotta, 2007, p. 120. 
RAMIRES, Celso Costa; ROCHA NETO, Odir Gomes da. A reforma dos Tribunais de Contas: uma revisão a partir das propostas de emendas constitucionais. Revista Eletrônica Direito e Política, Programa de Pós-Graduação Stricto Sensu em Ciência Jurídica da UNIVALI, Itajaí, v.10, n.2, $1^{\circ}$ quadrimestre de 2015. Disponível em: www.univali.br/direitoepolitica - ISSN 1980-7791.

(Agentes Públicos, Advogados, Defensores Públicos, Ministério Público junto ao Tribunal de Contas).

\section{DECLARAÇÃo DE LIMA SOBRE AS LINHAS BÁSICAS DA FISCALIZAÇÃo}

A Organização Internacional das Entidades Fiscalizadoras Superiores (INTOSAI), fundada em 1953, possui 192 membros de pleno direito e 5 membros associados e se constitui na organização central para os órgãos de fiscalização pública externa. No Brasil, o Tribunal de Contas da União participa da INTOSAI como Entidade Fiscalizadora Superior (EFS).

Em 1977, quando da IX INCOSAI, realizada no Peru, os membros da INTOSAI aprovaram a Declaração de Lima sobre as Linhas Básicas de Fiscalização com o objetivo principal de se exigir uma auditoria governamental independente. No Item "2" de tal declaração, afirma-se a necessidade da independência das EFS's, como se transcreve:

1. As Entidades Fiscalizadoras Superiores só podem desempenhar suas tarefas objetiva e eficazmente quando são independentes da entidade auditada e protegidas contra influências externas.

2. Embora as instituições do Estado não possam ser completamente independentes, pelo fato de fazerem parte do Estado como um todo, as Entidades Fiscalizadoras Superiores devem gozar da independência funcional e organizacional necessária para desempenhar suas tarefas.

3. O estabelecimento de Entidades Fiscalizadoras Superiores e do grau necessário de independência que devem gozar deve estar previsto na Constituição; detalhes podem ser estabelecidos na legislação. ${ }^{6}$

${ }^{6}$ Organización Internacional de las Entidades Fiscalizadoras Superiores (INTOSAI). Declaración de Lima sobre las Líneas Básicas de la Fiscalización. Tradução disponibilizada pelo Tribunal de Contas da União. Disponível em: http://portal2.tcu.gov.br/portal/page/portal/TCU/relacoes_institucionais/relacoes_internacionais/or ganizacoes_internacionais/DECLARA\%C3\%87\%C3\%830_DE_LIMA_PORT_0.pdf. Acesso em: 28 nov. 2014. 
RAMIRES, Celso Costa; ROCHA NETO, Odir Gomes da. A reforma dos Tribunais de Contas: uma revisão a partir das propostas de emendas constitucionais. Revista Eletrônica Direito e Política, Programa de Pós-Graduação Stricto Sensu em Ciência Jurídica da UNIVALI, Itajaí, v.10, n.2, $1^{\circ}$ quadrimestre de 2015. Disponível em: www.univali.br/direitoepolitica - ISSN 1980-7791.

Na Seção "5" desse documento, defende-se que os membros e diretores das EFS's devem possuir independência das entidades auditadas e protegidos contra influências externas. Por tais razões, devem gozar de independência funcional e organizacional necessária para realizar suas atividades.

Segundo a Declaração de Lima, tais prerrogativas de independência das EFS's devem estar descritas na Constituição de cada Estado signatário, podendo, os detalhes, estarem descritos na legislação infraconstitucional. De qualquer sorte, a forma de designação e destituição dos membros dependerá da estrutura constitucional e do modelo de controle externo adotado em cada país.

\section{MODELOS DE CONTROLE EXTERNO}

O controle externo da Administração Pública ocorre, fundamentalmente, por duas formas: a) Tribunais de Contas e b) Controladorias (ou Auditoria Geral).

Jacoby Fernandes ainda levanta um terceiro tipo de controle, chamado de "controle partidário". Tal modelo não será detalhado neste artigo por ter sido um exemplo histórico, que se caracterizava pela prestação de contas perante órgãos do partido único da antiga União das Repúblicas Socialistas Soviéticas (URSS). ${ }^{7}$

O primeiro modelo possui origem latina, conforme afirma Pascoal ${ }^{8}$, ou com influência da Europa continental, consoante Rocha ${ }^{9}$. São exemplos: Alemanha, França, Portugal, Bélgica, Áustria, Itália, Espanha, Comunidade Econômica

\footnotetext{
${ }^{7}$ FERNANDES, Jorge Ulisses Jacoby. Tribunais de Contas do Brasil: jurisdição e competência. $3^{a}$ ed. rev. atual. e ampl. Belo Horizonte: Fórum, 2012, p. 137-138.

8 PASCOAL, Valdecir Fernandes. Direito financeiro e controle externo: teoria, jurisprudência e 400 questões. Rio de Janeiro: Elsevier, 2008, p. 119.

${ }^{9}$ ROCHA, Carlos Alexandre Amorim. O Modelo de Controle Externo Exercido pelos Tribunais de Contas e as Proposições Legislativas sobre o Tema. Brasília: Senado Federal, Consultoria legislativa, 2002, p. 7. Disponível em: <http://www2.senado.leg.br/bdsf/item/id/156>. Acesso em 23 nov. 2014
} 
RAMIRES, Celso Costa; ROCHA NETO, Odir Gomes da. A reforma dos Tribunais de Contas: uma revisão a partir das propostas de emendas constitucionais. Revista Eletrônica Direito e Política, Programa de Pós-Graduação Stricto Sensu em Ciência Jurídica da UNIVALI, Itajaí, v.10, n.2, $1^{\circ}$ quadrimestre de 2015. Disponível em: www.univali.br/direitoepolitica - ISSN 1980-7791.

Europeia, Argélia, Coreia do Sul, Grécia, Uruguai, Argentina (províncias) ${ }^{10}$ e Japão.

Caracteriza-se pela formação de órgãos colegiados, geralmente com um presidente. Os membros são geralmente indicados pelo parlamento com mandatos limitados e possuindo as prerrogativas da magistratura judiciária ${ }^{11}$. Originalmente, preocupavam-se primordialmente com a formalidade de atos públicos, centrando-se nos aspectos de legalidade, mas com o tempo adotaram a avaliação por desempenho, a fim de avaliar a boa gestão pública. Das deliberações do Colegiado derivam as decisões em que preponderam as determinações aos administradores públicos.

Não se pode afirmar que todos os Tribunais de Contas são exatamente iguais, mas sim que se trata de modelo cujas influências históricas de cada país são marcantes na construção de cada instituição. A título de exemplo, o Conselho de Auditoria (Board of Audit) do Japão surgiu em 1869 da divisão das funções do Ministro das Finanças. Adquiriu natureza constitucional em 1889, com a Constituição Meiji, passando a ser um órgão independente subordinado ao Imperador. Em 1947, tornou-se independente do Poder Executivo, não pertencendo mais a nenhum dos demais Poderes ${ }^{12}$. O órgão abrange a Audit Comission, órgão decisório, que atua de forma separada do General Executive Bureau, que corresponde ao órgão executivo. ${ }^{13}$

O Tribunal de Contas Europeu possui um órgão colegiado com 28 membros, sendo um de cada Estado-Membro, para um mandato de seis anos renovável. Tais membros elegem um presidente a cada três anos. O Secretário-Geral, funcionário de grau mais elevado do quadro de servidores, é nomeado pelo

\footnotetext{
10 PASCOAL, Valdecir Fernandes. Direito financeiro e controle externo: teoria, jurisprudência e 400 questões. p. 119.

${ }^{11}$ PASCOAL, Valdecir Fernandes. Direito financeiro e controle externo: teoria, jurisprudência e 400 questões. p. 119-120.

12 JAPAN. Board of Audit of Japan. History of the Board. Disponível em: <http://www.jbaudit.go.jp/english/jbaudit/history.html>. Acesso em: 12 mar. 2015.

13 JAPAN. Board of Audit of Japan. Organization of the Board. Disponível em: < http://www.jbaudit.go.jp/english/jbaudit/organization.html>. Acesso em: 12 mar. 2015.
} 
RAMIRES, Celso Costa; ROCHA NETO, Odir Gomes da. A reforma dos Tribunais de Contas: uma revisão a partir das propostas de emendas constitucionais. Revista Eletrônica Direito e Política, Programa de Pós-Graduação Stricto Sensu em Ciência Jurídica da UNIVALI, Itajaí, v.10, n.2, 10 quadrimestre de 2015. Disponível em: www.univali.br/direitoepolitica - ISSN 1980-7791.

Tribunal para mandato de seis anos renovável. Segundo informa o portal do órgão, atuam 900 funcionários entre auditores, tradutores e administração. ${ }^{14}$

Consoante Jacoby Fernandes, "a maioria dos países do mundo adota o sistema de tribunal." ${ }^{15}$ Para ele, o fato da União Europeia ter criado um Tribunal de Contas para o bloco, demonstra a adequação desse modelo para fazer frente às contingências do futuro.

O segundo modelo organiza-se na forma de Auditorias-Gerais ou controladorias, sendo mais comum nos países de origem anglo-saxônica, dos quais são exemplos: Inglaterra, África do Sul, Austrália, Canadá, Estados Unidos, Dinamarca, Índia, Irlanda, Israel, Chile, Irlanda, México, Venezuela, Colômbia, Costa Rica, Argentina (Governo Federal) ${ }^{16}$ e República Popular da China.

Estrutura-se na forma de órgão unipessoal, comandado por um controlador geral, com mandato limitado. Quanto ao enfoque do controle, Rocha afirma que "o controle gerencial (...) é a principal marca das Auditorias-Gerais ou Controladorias. ${ }^{17} \mathrm{Em}$ tal controle, prioriza-se a análise de desempenho nos atos administrativos, passando estes por avaliação de eficiência $^{18}$, eficácia $^{19}$ e

14 UNIÃO EUROPEIA. Tribunal de Contas Europeu. Governação. Disponível em: <http://www.eca.europa.eu/pt/Pages/Structure.aspx>. Acesso em: 12 mar. 2015.

${ }^{15}$ FERNANDES, Jorge Ulisses Jacoby. Tribunais de Contas do Brasil: jurisdição e competência. p. 136.

16 PASCOAL, Valdecir Fernandes. Direito financeiro e controle externo: teoria, jurisprudência e 400 questões. p. 120.

\footnotetext{
${ }^{17}$ ROCHA, Carlos Alexandre Amorim. O Modelo de Controle Externo Exercido pelos Tribunais de Contas e as Proposições Legislativas sobre o Tema. p. 7.
}

18 Utiliza-se o termo eficiência no sentido de "racionalidade com que os recursos alocados a determinados programas governamentais são aplicados. Refere-se à extensão em que a unidade econômica maximiza seus benefícios com um mínimo de utilização de tempo e recursos. Preocupase com os meios, os métodos e os procedimentos planejados e organizados, a fim de assegurar a otimização da utilização dos recursos disponíveis". [Normas de Auditoria Governamental - NAGs: Aplicáveis ao Controle Externo. Elaborado sob a coordenação do Instituto Rui Barbosa (IRB) e ATRICON, com apoio do Ministério do Planejamento, Orçamento e Gestão (MPOG) e Banco Mundial (BID). 2010, p. 13. Disponível em: http://www.controlepublico.org.br/files/Proposta-deAnteprojeto-NAGs_24-11.pdf, acesso em 18 fev. 2015.]

19 O termo eficácia "diz respeito ao grau de realização de objetivos e de alcance das metas". [Normas de Auditoria Governamental - NAGs: Aplicáveis ao Controle Externo. Elaborado sob a coordenação do Instituto Rui Barbosa (IRB) e ATRICON, com apoio do Ministério do Planejamento, Orçamento e Gestão (MPOG) e Banco Mundial (BID). 2010, p. 13.] 
RAMIRES, Celso Costa; ROCHA NETO, Odir Gomes da. A reforma dos Tribunais de Contas: uma revisão a partir das propostas de emendas constitucionais. Revista Eletrônica Direito e Política, Programa de Pós-Graduação Stricto Sensu em Ciência Jurídica da UNIVALI, Itajaí, v.10, n.2, 10 quadrimestre de 2015. Disponível em: www.univali.br/direitoepolitica - ISSN 1980-7791.

efetividade ${ }^{20}$, de custos e benefícios, e comparação entre os resultados planejados e almejados.

Jacoby Fernandes explica que o modelo nasceu na Inglaterra, sendo posteriormente adotado pelo Congresso Americano ${ }^{21}$. Pascoal leciona que na Inglaterra, "o Controlador Geral assessora a comissão de contas públicas da Câmara dos Comuns, exerce auditoria sobre as contas dos departamentos de governo e confere se a aplicação se deu corretamente e para suas finalidades". ${ }^{22}$ Para tanto, possui quadro de auditores, que podem ou não atuar dentro dos órgãos de governo. Iocken informa que, em novembro de 2012, cerca de 700 auditores foram transferidos para o setor privado, encerrando a comissão de auditoria (Audit Comission) ${ }^{23}$.

Nos Estados Unidos da América do Norte, o General Office Accounting surgiu em 1921, como meio de recuperar o controle das finanças públicas após a Primeira Guerra Mundial. Até então, a auditoria externa era realizada pelo Tesouro Nacional. É uma agência independente, não partidária, comandada por um Controlador-Geral. Inicialmente, o Congresso Nacional apresenta lista de candidatos ao Presidente da República, que recomenda a nomeação de um destes. Depois, o Senado Federal sabatina-o, confirmando ou não a indicação presidencial. Em caso positivo, o Presidente da República nomeia o Controlador-

\footnotetext{
20 O termo efetividade "refere-se ao resultado real obtido pelos destinatários das políticas, dos programas e dos projetos públicos. É o impacto proporcionado pela ação governamental." [Normas de Auditoria Governamental - NAGs: Aplicáveis ao Controle Externo. Elaborado sob a coordenação do Instituto Rui Barbosa (IRB) e ATRICON, com apoio do Ministério do Planejamento, Orçamento e Gestão (MPOG) e Banco Mundial (BID). 2010, p. 13.]

${ }^{21}$ FERNANDES, Jorge Ulisses Jacoby. Tribunais de Contas do Brasil: jurisdição e competência.p. 137.

${ }^{22}$ PASCOAL, Valdecir Fernandes. Direito financeiro e controle externo: teoria, jurisprudência e 400 questões. p. 120.

${ }^{23}$ IOCKEN, Sabrina Nunes. Políticas Públicas: O controle do tribunal de contas. Florianópolis: conceito Editorial, 2014, p. 47.
} 
RAMIRES, Celso Costa; ROCHA NETO, Odir Gomes da. A reforma dos Tribunais de Contas: uma revisão a partir das propostas de emendas constitucionais. Revista Eletrônica Direito e Política, Programa de Pós-Graduação Stricto Sensu em Ciência Jurídica da UNIVALI, Itajaí, v.10, n.2, $1^{\circ}$ quadrimestre de 2015. Disponível em: www.univali.br/direitoepolitica - ISSN 1980-7791.

Geral. ${ }^{24}$ Conforme Jacoby Fernandes, o escritório geral de auditoria (General Office Accounting - GAO) integra o Poder Legislativo. ${ }^{25}$

A Constituição chinesa, nos artigos 62, 67,80 e 86, preveem a nomeação de Auditor-Geral pelo Premier, mediante a aprovação do Congresso Nacional do Povo ou de seu comitê. O escritório de auditoria encontra-se subordinado ao governo do povo, fazendo parte do Poder Executivo. ${ }^{26}$

Para Jacoby Fernandes, o modelo tribunal apresenta mais vantagens do que a Auditoria-Geral. Elenca como fatores positivos do primeiro: "a) atuação em colegiado; b) alternância de direção; c) rodízio no controle dos órgãos; d) distribuição impessoal de processos." 27

Ambos os modelos de controle podem ter as suas instituições vinculadas a qualquer poder. Todavia, não existem exemplos de controladores com vinculação ao Poder Judiciário, bem como não é comum nas cortes de contas. Afirma Rocha que, em geral, a ligação dos órgãos de controle ocorre com o Poder Legislativo. ${ }^{28}$

\section{TRIBUNAIS DE CONTAS E CONTROLE EXTERNO}

O Brasil adota o modelo de Tribunais de Contas, caracterizando-se estes como órgãos independentes que auxiliam o Poder Legislativo na execução do controle externo. Essa é a lição de Jacoby Fernandes. "O controle externo é função afeta ao Poder Legislativo, que a exerce com o auxílio do Tribunal de Contas. Auxilia

\footnotetext{
24 UNITED STATES. General Accouting Office. Disponível em: <http://www.gao.gov/about/cgprocess.html>. Acesso em: 12 mar. 2015.

${ }^{25}$ FERNANDES, Jorge Ulisses Jacoby. Tribunais de Contas do Brasil: jurisdição e competência. p. 137.

26 REPÚBLICA POPULAR DA CHINA. National Audit Office of the People's Republic of China. About us. Legal status. Auditing System. Disponível em: <http://www.cnao.gov.cn/main/AboutUs_ArtID_726.htm>. Acesso em: 12 mar. 2015.

27 FERNANDES, Jorge Ulisses Jacoby. Tribunais de Contas do Brasil: jurisdição e competência. p. 137.

${ }^{28} \mathrm{ROCHA}$, Carlos Alexandre Amorim. O Modelo de Controle Externo Exercido pelos Tribunais de Contas e as Proposições Legislativas sobre o Tema. p. 8.
} 
RAMIRES, Celso Costa; ROCHA NETO, Odir Gomes da. A reforma dos Tribunais de Contas: uma revisão a partir das propostas de emendas constitucionais. Revista Eletrônica Direito e Política, Programa de Pós-Graduação Stricto Sensu em Ciência Jurídica da UNIVALI, Itajaí, v.10, n.2, 10 quadrimestre de 2015. Disponível em: www.univali.br/direitoepolitica - ISSN 1980-7791.

exercendo uma função, não assessorando, nem se submetendo a qualquer dos poderes $^{\prime 29}$.

Segundo Pascoal, o Tribunal de Contas apresenta-se como um:

(...) órgão constitucional dotado de autonomia administrativa e financeira, sem qualquer relação de subordinação com os Poderes Executivo, Legislativo e Judiciário. (...) O TC é um órgão de permeio, agindo ora numa posição de colaboração com o Poder Legislativo, ora no exercício de suas competências próprias. ${ }^{30}$

Na mesma esteira, leciona Oliveira ao se pronunciar sobre o Tribunal de Contas como:

(...) um órgão constitucional a quem cabe a fiscalização e controle das contas de todas as pessoas jurídicas e físicas que lidam com recursos públicos, a apreciação da legalidade dos serviços funcionais, podendo impor sanções, em casos de infração. Não é órgão integrante de qualquer poder, possuindo dignidade político-administrativa própria. ${ }^{31}$

Ayres Brito leciona que "o Tribunal de Contas da União não é órgão do Congresso Nacional, não é órgão do Poder Legislativo"32. Nas palavras dele, tal corte "não é órgão auxiliar do Parlamento nacional, naquele sentido de inferioridade hierárquica ou subalternidade funcional." ${ }^{33}$ Para o autor, o órgão (Tribunal de Contas da União) pertence a pessoa jurídica da União, diretamente, sem pertencer a nenhum dos três Poderes Federais. ${ }^{34}$

\footnotetext{
${ }^{29}$ FERNANDES, Jorge Ulisses Jacoby. Tribunais de Contas do Brasil: jurisdição e competência. p. 166.

${ }^{30}$ PASCOAL, Valdecir Fernandes. Direito financeiro e controle externo: teoria, jurisprudência e 400 questões. p. 126.

${ }^{31}$ OLIVEIRA, Regis Fernandes de. Manual de direito financeiro. 3. ed. São Paulo: Revista dos Tribunais, 2007, p. 504.

32 BRITO, Carlos Ayres. O Regime Constitucional dos Tribunais de Contas. In: SOUZA, Alfredo José de et al. O Novo Tribunal de Contas: Órgão Protetor dos Direitos Fundamentais. Belo Horizonte: Fórum, 2004. p. 176-178.

33 BRITO, Carlos Ayres. O Regime Constitucional dos Tribunais de Contas. In: SOUZA, Alfredo José de et al. O Novo Tribunal de Contas: Órgão Protetor dos Direitos Fundamentais. p. 176-178.

34 BRITO, Carlos Ayres. O Regime Constitucional dos Tribunais de Contas. In: SOUZA, Alfredo José de et al. O Novo Tribunal de Contas: Órgão Protetor dos Direitos Fundamentais. p. 176-178.
} 
RAMIRES, Celso Costa; ROCHA NETO, Odir Gomes da. A reforma dos Tribunais de Contas: uma revisão a partir das propostas de emendas constitucionais. Revista Eletrônica Direito e Política, Programa de Pós-Graduação Stricto Sensu em Ciência Jurídica da UNIVALI, Itajaí, v.10, n.2, 10 quadrimestre de 2015. Disponível em: www.univali.br/direitoepolitica - ISSN 1980-7791.

Celso Antônio Bandeira de Mello ${ }^{35}$ comunga do mesmo entendimento de Ayres Brito. Após mencionar diversos mestres, conclui que os Tribunais de Contas são órgãos autônomos, não se situando no Poder Executivo, nem no Judiciário, nem no Legislativo.

Para que algo se possa considerar interior, intestino a um corpo orgânico cumpre que existem os vínculos de subordinação, o liame hierárquico ou, quando menos, o vínculo de controle. Um dos dois teria que existir e, no caso do Tribunal de Contas, não existe. O Tribunal de Contas, em verdade, não é subordinado ao Legislativo, nem está sob a tutela dele. ${ }^{36}$

Resulta que o Tribunal de Contas possui autonomia em relação ao Poder Legislativo, podendo realizar as suas atribuições de forma independente, no intuito de auxiliar o Poder Legislativo na realização do controle externo dos demais Poderes, cabendo no caso das Cortes de Contas, inclusive a fiscalização do Poder Legislativo. ${ }^{37}$

Os Tribunais de Contas no Brasil constituem-se em órgãos da União, Estados e Municípios, sem existir cortes superiores para uniformizar a interpretação infraconstitucional e constitucional como acontece no Poder Judiciário. Leciona Jacoby Fernandes que o funcionamento dos Tribunais de Contas não acontece de forma integrada. Tais órgãos buscam se integrar com atos de colaboração ou convênios, mas a separação "dificulta a ação do controle, se envolvidos recursos de mais de uma esfera de governo". ${ }^{38}$

\footnotetext{
${ }^{35}$ MELLO, Celso Antônio Bandeira de. O enquadramento constitucional do Tribunal de Contas. In: FREITAS, Ney José de (Org.). Tribunais de Contas: Aspectos polêmicos: estudos em homenagem ao Conselheiro João Féder. Belo Horizonte: Fórum, 2009. p. 70.

36 MELLO, Celso Antônio Bandeira de. O enquadramento constitucional do Tribunal de Contas. In: FREITAS, Ney José de (Org.). Tribunais de Contas: Aspectos polêmicos: estudos em homenagem ao Conselheiro João Féder. p. 68.

37 ROCHA NETO, Odir Gomes da. Adesão (Carona) à ata de registro de preços na visão dos tribunais de contas. Monografia (Especialização em Estudos Estratégicos em Administração Pública). Universidade do Estado de Santa Catarina - UDESC. Florianópolis, 2011, p.17. Disponível em: $\quad<$ http://www.enabrasil.sc.gov.br/assets/anexos/pdf/de61f8daaa31659adc b37651d356abce2012_07_18_22_08_24.pdf>. Acesso em: 09 mar. 2015.

${ }^{38}$ FERNANDES, Jorge Ulisses Jacoby. Tribunais de Contas do Brasil: jurisdição e competência. p. 780.
} 
RAMIRES, Celso Costa; ROCHA NETO, Odir Gomes da. A reforma dos Tribunais de Contas: uma revisão a partir das propostas de emendas constitucionais. Revista Eletrônica Direito e Política, Programa de Pós-Graduação Stricto Sensu em Ciência Jurídica da UNIVALI, Itajaí, v.10, n.2, $1^{\circ}$ quadrimestre de 2015. Disponível em: www.univali.br/direitoepolitica - ISSN 1980-7791.

Há, nos dias atuais, trinta e quatro Tribunais de Contas, sendo um da União; dois exclusivamente de um município, a saber, o Tribunal de Contas do Rio de Janeiro e o do Município de São Paulo; nos Estados de Goiás, Bahia, Pará e Ceará, coexistem os Tribunais de Contas do Estado e Tribunais de Contas dos Municípios daquele Estado; enquanto nos demais vinte e dois Estados e no Distrito Federal, tem-se apenas a existência do Tribunal de Contas do Estado, cuja responsabilidade se estende aos Municípios daquele ente federativo. ${ }^{39}$

Os Tribunais de Contas do Município de São Paulo e Rio de Janeiro são responsáveis pela fiscalização dos recursos públicos de cada uma dessas cidades. Nos Estados em que existem os Tribunais de Contas Estaduais e Municipais, aqueles são responsáveis pelo controle externo das contas dos Estados, ficando a cargo destes a atuação sob as finanças municipais. Naqueles Estados em que há apenas os Tribunais de Contas Estaduais, este fica responsável pela fiscalização das contas do Estado e dos Municípios. O Supremo Tribunal Federal, ao julgar a ADI no 596/RJ, pacificou entendimento de que os Estados podem criar Tribunais de Contas dos Municípios. Ao mesmo tempo, vedou aos Municípios a permissão para criarem tais órgãos.

O Tribunal de Contas da União (TCU) é um órgão previsto no artigo 70 da Constituição da República Federativa de 1988 (CRFB/88), o qual deve auxiliar o Poder Legislativo na fiscalização contábil, financeira, orçamentária, operacional e patrimonial da União, Estados e Municípios e das entidades da administração direta e indireta, bem como os responsáveis pela utilização de dinheiro público, inclusive pessoas físicas e jurídicas privadas, quanto à legalidade, legitimidade e economicidade. ${ }^{40}$

Por um princípio de simetria, o artigo 75 da CRFB/88 estabelece que se aplicam aos Tribunais de Contas Estaduais e Municipais, no que couber, todas as

\footnotetext{
39 ROCHA NETO, Odir Gomes da. Adesão (Carona) à ata de registro de preços na visão dos tribunais de contas. p. 15-16.

40 BRASIL. Constituição (1988). Constituição da República Federativa do Brasil. Disponível em: <http://www.planalto.gov.br/ccivil_03/constituicao/ constituicao.htm>. Acesso em: 02 abr. 2015.
} 
RAMIRES, Celso Costa; ROCHA NETO, Odir Gomes da. A reforma dos Tribunais de Contas: uma revisão a partir das propostas de emendas constitucionais. Revista Eletrônica Direito e Política, Programa de Pós-Graduação Stricto Sensu em Ciência Jurídica da UNIVALI, Itajaí, v.10, n.2, $1^{\circ}$ quadrimestre de 2015. Disponível em: www.univali.br/direitoepolitica - ISSN 1980-7791.

competências, forma de organização e o poder fiscalizatório que são do Tribunal de Contas da União. ${ }^{41}$

O Tribunal de Contas da União não possui uma força vinculante ao proferir suas decisões e nem se constitui em órgão de segunda instância, apesar do verbete da súmula no 222 do TCU afirmar que a interpretação dada por esta Corte de Contas sobre as normas gerais de licitação deva ser acatada pelos administradores da União, Estados e Municípios. ${ }^{42}$

Como já mencionado, não se trata de um sistema hierarquizado onde o Tribunal de Contas da União se encontra no ápice, pelo contrário, cada Corte possui autonomia financeira, administrativa e decisória. ${ }^{43}$

O Tribunal de Contas da União é formado por nove Ministros, assim escolhidos: um terço pelo Presidente da República, com a chancela do Senado Federal, sendo dois alternadamente dentre auditores e membros do Ministério Público junto ao Tribunal e o terceiro de livre escolha; e dois terços pelo Congresso Nacional. ${ }^{44}$

Para serem nomeados, conforme o artigo 73, $\S 10$, da CRFB/88, devem possuir mais de trinta e cinco e menos de sessenta e cinco anos de idade; idoneidade moral e reputação ilibada; notórios conhecimentos jurídicos, contábeis, econômicos e financeiros ou de administração pública, além de mais de dez anos de exercício de função ou de efetiva atividade profissional que exija os conhecimentos mencionados no inciso anterior. ${ }^{45}$

Os Ministros possuem os mesmos direitos e prerrogativas dos magistrados. Dessa forma, eles são vitalícios no cargo até a aposentadoria compulsória aos 70

\footnotetext{
${ }^{41}$ BRASIL. Constituição (1988). Constituição da República Federativa do Brasil.

42 ROCHA NETO, Odir Gomes da. Adesão (Carona) à ata de registro de preços na visão dos tribunais de contas. p. 16.

${ }^{43}$ ROCHA NETO, Odir Gomes da. Adesão (Carona) à ata de registro de preços na visão dos tribunais de contas. p. 16.

${ }^{44}$ NAGEL, José. A fisionomia distorcida do controle externo. Revista TCU. Brasília, v. 31, n. 86, out/dez 2000, p. 27.

${ }^{45}$ BRASIL. Constituição (1988). Constituição da República Federativa do Brasil.
} 
RAMIRES, Celso Costa; ROCHA NETO, Odir Gomes da. A reforma dos Tribunais de Contas: uma revisão a partir das propostas de emendas constitucionais. Revista Eletrônica Direito e Política, Programa de Pós-Graduação Stricto Sensu em Ciência Jurídica da UNIVALI, Itajaí, v.10, n.2, $1^{\circ}$ quadrimestre de 2015. Disponível em: www.univali.br/direitoepolitica - ISSN 1980-7791.

anos. Na ausência dos Ministros, estes serão substituídos pelos auditores, conforme art. 77 e 78 da Lei no 8.443/92, que também serão nomeados pelo Presidente da República, após aprovação em concurso público de provas e títulos. Assim, os Ministros e os auditores são considerados membros do Tribunal de Contas da União. ${ }^{46}$

As Cortes de Contas Estaduais, a seu tempo, devem possuir sete Conselheiros, de acordo com o parágrafo único do artigo 75 da CRFB/88, cabendo a cada Constituição Estadual estabelecer a forma de nomeação e escolha. Por simetria, consoante verbete da súmula 653 do STF, quatro Conselheiros são escolhidos pela Assembleia Legislativa e três pelo chefe do Poder Executivo Estadual, cabendo a este indicar um entre auditores, outro entre os membros do Ministério público e um terceiro à sua livre escolha. ${ }^{47}$

A Corte de Contas da União também possui quadro de pessoal próprio regido pela Lei no 10.356/2001, com a modificação do artigo $4^{\circ}$ da Lei no 11.950/2009 e outras modificações. Compõe-se dos cargos efetivos de Auditor Federal de Controle Externo, Técnico Federal de Controle Externo e Auxiliar de Controle Externo; e dos cargos em comissão permitidos constitucionalmente. ${ }^{48}$ Convém salientar que os auditores mencionados no artigo $73, \S 3^{\circ}$, da Constituição, são distintos dos Auditores Federais de Controle Externo. Aqueles substituem os Ministros, respondem pela instrução processual e emitem proposta de voto para os integrantes do Plenário ou Câmara. Os Auditores Federais de Controle Externo, por sua vez, são credenciados pelo Presidente do Tribunal de Contas da União ou, por delegação deste, pelos dirigentes das unidades técnicas da secretaria do TCU, para desempenhar funções de auditoria e de inspeções.

\footnotetext{
46 BRASIL. Lei $\mathbf{n}^{\circ} \mathbf{8 . 4 4 3}$, de 16 de Julho de 1992. Lei Orgânica do TCU. Dispõe sobre a Lei Orgânica do Tribunal de Contas da União e dá outras providências. Disponível em: http://www2.camara.gov.br/legin/fed/lei/1992/lei-8443-16-julho-1992-365298-norma-pl.html. Acesso em: 24 nov. 2014.

${ }^{47}$ BRASIL. Constituição (1988). Constituição da República Federativa do Brasil.

${ }^{48}$ BRASIL. Lei no 10.356 de 27 de Dezembro de 2001. Dispõe sobre o Quadro de Pessoal e o Plano de Carreira do Tribunal de Contas da União e dá outras providências. Disponível em: http://www.planalto.gov.br/ccivil_03/leis/LEIS_2001/L10356.htm. Acesso em: 23 nov. 2014.
} 
RAMIRES, Celso Costa; ROCHA NETO, Odir Gomes da. A reforma dos Tribunais de Contas: uma revisão a partir das propostas de emendas constitucionais. Revista Eletrônica Direito e Política, Programa de Pós-Graduação Stricto Sensu em Ciência Jurídica da UNIVALI, Itajaí, v.10, n.2, $1^{\circ}$ quadrimestre de 2015. Disponível em: www.univali.br/direitoepolitica - ISSN 1980-7791.

Os cargos de chefia, assessoramento e direção da Secretaria do TCU são definidos pelo Presidente do órgão entre os servidores. Consoante artigo 30 , II e $\S 20$, da Lei no $10.356 / 2001$, os ocupantes de cargos comissionados destinados aos Gabinetes de Ministro e de Auditor são de livre escolha das respectivas autoridades, enquanto os demais são destinados exclusivamente aos servidores de cargo de provimento da Secretaria do TCU. ${ }^{49}$

Por fim, cabe salientar que inexiste órgão superior de controle administrativo do Tribunal de Contas da União ou das Cortes Estaduais. Por não ser órgão do Poder Judiciário, encontra-se fora da competência do Conselho Nacional de Justiça, frente à leitura do $\S 4^{\circ}$ do artigo $103-B$ da CRFB/88. ${ }^{50}$

Encontram-se delineados no modelo de controle externo, a que Poder do Estado estão vinculadas as Cortes de Contas, a organização do sistema de controle externo, a composição, a forma de nomeação e o quadro de pessoal. Com tais elementos, torna-se possível comparar as diversas emendas constitucionais propostas.

\section{REFORMAS DOS TRIBUNAIS DE CONTAS}

Em 1996, o Conselheiro aposentado Salomão Ribas Junior já ventilava ideias sobre como seria o futuro dos Tribunais de Contas. Ele avisava que o processo de recrutamento de auditores, procuradores e conselheiros dos Tribunais de Contas iria mudar. Ribas Junior defendia a escolha de um sistema apoiado pela sociedade, que poderia incluir múltiplos processos de escolha, abrangendo o ingresso direto em um Tribunal de Contas e a escolha de servidores públicos de longa experiência. Alertava que a escolha por concurso público pode

\footnotetext{
${ }^{49}$ BRASIL. Lei no 10.356 de 27 de Dezembro de 2001.

${ }^{50}$ ROCHA NETO, Odir Gomes da. Adesão (Carona) à ata de registro de preços na visão dos tribunais de contas.
} 
RAMIRES, Celso Costa; ROCHA NETO, Odir Gomes da. A reforma dos Tribunais de Contas: uma revisão a partir das propostas de emendas constitucionais. Revista Eletrônica Direito e Política, Programa de Pós-Graduação Stricto Sensu em Ciência Jurídica da UNIVALI, Itajaí, v.10, n.2, 10 quadrimestre de 2015. Disponível em: www.univali.br/direitoepolitica - ISSN 1980-7791.

democratizar a escolha, mas não era garantia da escolha do melhor servidor público. ${ }^{51}$

Sabrina Nunes Iocken, auditora substituta, ao tratar da legitimidade da judicatura de contas, critica o ingresso majoritário de pessoas desvinculadas às carreiras técnicas nos cargos de conselheiros/ministros ${ }^{52}$. Afirma que a aludida desproporcionalidade "compromete o requisito da confiabilidade quanto ao julgamento imparcial". ${ }^{53}$

Ao citar Cláudio Augusto Canha, Iocken relembra que, no início da elaboração do texto constitucional, os Tribunais de Contas seriam formados com 3 vagas destinadas aos auditores substitutos de Conselheiros/Ministros, sendo reduzido para a atual uma vaga destinada a estes cargos. ${ }^{54}$

As críticas ao atual modelo de controle não permaneceram apenas na seara doutrinária. Os congressistas têm proposto diversas emendas constitucionais ao longo dos anos no intuito de modificar, aprimorar ou extinguir as Cortes de Contas.

Em 2002, Carlos Alexandre Amorim Rocha elaborou denso estudo sobre os modelos de Controle Externo apresentando as propostas de emendas constitucionais (PEC's) existentes entre 1996 e 2001, conforme demonstra o quadro abaixo:

Quadro 1: Propostas de Emendas Constitucionais envolvendo os tribunais de contas nos anos de 1996 e 2001.

\footnotetext{
51 RIBAS JUNIOR. Salomão. Uma viagem a Hessen: a função dos Tribunais de Contas: as realidades no Brasil e na Alemanha. Tribunal de Contas do Estado de Santa Catarina: Florianópolis, 1996, p. 131.

52 IOCKEN, Sabrina Nunes. Em busca da legitimidade da judicatura de contas: O modelo constitucional. In: LIMA, Luiz Henrique (Coord.). Tribunais de Contas: Temas polêmicos na visão de ministros e conselheiros substitutos. Belo Horizonte: Fórum, 2014. p. 203-204.

53 IOCKEN, Sabrina Nunes. Em busca da legitimidade da judicatura de contas: O modelo constitucional. In: LIMA, Luiz Henrique (Coord.). Tribunais de Contas: Temas polêmicos na visão de ministros e conselheiros substitutos. p. 204.

54 CANHA, Cláudio Augusto apud IOCKEN, Sabrina Nunes. Em busca da legitimidade da judicatura de contas: O modelo constitucional. In: LIMA, Luiz Henrique (Coord.). Tribunais de Contas: Temas polêmicos na visão de ministros e conselheiros substitutos. p. 204.
} 
RAMIRES, Celso Costa; ROCHA NETO, Odir Gomes da. A reforma dos Tribunais de Contas: uma revisão a partir das propostas de emendas constitucionais. Revista Eletrônica Direito e Política, Programa de Pós-Graduação Stricto Sensu em Ciência Jurídica da UNIVALI, Itajaí, v.10, n.2, $1^{\circ}$ quadrimestre de 2015. Disponível em: www.univali.br/direitoepolitica - ISSN 1980-7791.

\begin{tabular}{|c|c|}
\hline $\begin{array}{c}\text { TIPO E } \\
\text { NÚMERO }\end{array}$ & ASSUNTO \\
\hline PEC 442/1996 & Critérios de nomeação dos ministros. \\
\hline PEC 556/1997 & Critérios de nomeação dos ministros. \\
\hline PEC 19/1999 & $\begin{array}{l}\text { Extinção dos tribunais e conselho de contas dos } \\
\text { municípios. }\end{array}$ \\
\hline PEC 39/1999 & $\begin{array}{l}\text { Transferência das atribuições dos tribunais e conselho } \\
\text { de contas dos municípios para os tribunais de contas } \\
\text { dos estados. }\end{array}$ \\
\hline PEC 50/1999 & Critérios de nomeação dos ministros. \\
\hline PEC $123 / 1999$ & Critérios de nomeação dos ministros. \\
\hline PEC $11 / 2000$ & Nomeação de auditor para ministro. \\
\hline PEC 25/2000 & $\begin{array}{l}\text { Faculdade de nomear membros das cortes de contas } \\
\text { estaduais e municipais mediante concurso público. }\end{array}$ \\
\hline PEC $192 / 2000$ & $\begin{array}{l}\text { Extinção dos tribunais de contas municipais e das } \\
\text { cidades do Rio de Janeiro e de São Paulo. }\end{array}$ \\
\hline PEC $193 / 2000$ & $\begin{array}{l}\text { Extinção dos tribunais de contas da União, dos estados } \\
\text { e dos municípios. Criação da Auditoria-Geral da União. }\end{array}$ \\
\hline PEC 293/2000 & Mandato dos conselheiros. \\
\hline PEC 329/2001 & $\begin{array}{l}\text { Extinção dos tribunais de contas da União, dos estados } \\
\text { e dos municípios. Criação da Comissão Mista } \\
\text { Permanente no Congresso Nacional. }\end{array}$ \\
\hline
\end{tabular}

Fonte: ROCHA, Carlos Alexandre Amorim. O Modelo de Controle Externo Exercido pelos Tribunais de Contas e as Proposições Legislativas sobre o Tema. 2002, p. 39-41.

Desde 1996 já se percebe a intenção dos legisladores nacionais em alterar a forma de nomeação das Cortes de Contas. Com a PEC no 193/2000, o anseio passou a ser em extinguir os Tribunais de Contas para se criar a Auditoria-Geral. Todavia, os anos se passaram e nenhuma das propostas foi aprovada até o fim de 2014. Por outro lado, os congressistas mantiveram a discussão sobre o 
RAMIRES, Celso Costa; ROCHA NETO, Odir Gomes da. A reforma dos Tribunais de Contas: uma revisão a partir das propostas de emendas constitucionais. Revista Eletrônica Direito e Política, Programa de Pós-Graduação Stricto Sensu em Ciência Jurídica da UNIVALI, Itajaí, v.10, n.2, $1^{\circ}$ quadrimestre de 2015. Disponível em: www.univali.br/direitoepolitica - ISSN 1980-7791.

modelo de controle externo ao lançarem as propostas de Emendas Constitucionais de nos. 15/2007, 30/2007, 75/2007, 90/2007 e 329/2013, agregando modificações profundas na estrutura dos Tribunais de Contas.

A PEC no 15, de 06 de março de 2007, proposta pelo Senador Renato Casagrande, foi arquivada em 26 de dezembro de 2014, em razão do final da 54a legislatura. Visava alterar a forma de ingresso e exoneração dos ministros e conselheiros. ${ }^{55}$

A PEC no 30, de 11 de abril de 2007, de autoria do Senador Renato Casagrande e outros senadores, encontra-se arquivada em razão do final da 54a legislatura. Tinha como objetivo a criação do Conselho Nacional dos Tribunais de Contas e outras providências. ${ }^{56}$

A PEC no 75, de 30 de maio de 2007, proposta pela deputada Alice Portugal e outros deputados, foi desarquivada em 06 de fevereiro de 2015, por requerimento da autora. Objetiva reestruturar os Tribunais de Contas da União e dos Estados, criando a Auditoria de Controle Externo dentro dos Tribunais. Ao mesmo tempo, busca ampliar a participação dos servidores nas atividades das Cortes de Contas. ${ }^{57}$

A PEC no 90, de 16 de outubro de 2007, proposta pela senadora Serys Slhessarenko e outros senadores, visa extinguir os Tribunais de Contas, os cargos de Ministro e de Conselheiros dos Tribunais de Contas, e criar as

\footnotetext{
${ }^{55}$ BRASIL. Senado Federal. Proposta de Emenda à Constituição no 15/2007. Disponível em: $<$ http://www.senado.leg.br/atividade/materia/detalhes.asp?p_cod_mate=80082>. Acesso em: 02 abr. 2015.

${ }^{56}$ BRASIL. Senado Federal. Proposta de Emenda à Constituição no 30/2007. Disponível em: $<$ http://www.senado.gov.br/atividade/materia/detalhes.asp?p_cod_mate=80566>. Acesso em 02 abr. 2015.

57 BRASIL. Câmara dos Deputados. Proposta de Emenda à Constituição no 75/2007. Disponível em: <http://www.camara.gov.br/proposicoesWeb/fichadetramitacao?idProposicao= 353740>. Acesso em 02 abr. 2015.
} 
RAMIRES, Celso Costa; ROCHA NETO, Odir Gomes da. A reforma dos Tribunais de Contas: uma revisão a partir das propostas de emendas constitucionais. Revista Eletrônica Direito e Política, Programa de Pós-Graduação Stricto Sensu em Ciência Jurídica da UNIVALI, Itajaí, v.10, n.2, $1^{\circ}$ quadrimestre de 2015. Disponível em: www.univali.br/direitoepolitica - ISSN 1980-7791.

Auditorias de Contas. Tal proposta foi arquivada em 26 de dezembro de 2014, diante do final da $54^{a}$ legislatura. ${ }^{58}$

A PEC no 329, proposta pelo deputado Francisco Praciano e outros deputados, em 17 de outubro de 2013, encontra-se arquivada a partir de 31 de janeiro de 2015, em face do final da 54a legislatura. Em sua ementa consta que pretende alterar a forma de composição dos Tribunais de Contas; submeter os Conselheiros e Ministros dos Tribunais de Contas ao Conselho Nacional de Justiça (CNJ) e outras providências. ${ }^{59}$

A partir dos seguintes elementos estruturantes, avalia-se comparativamente tais propostas: modelo de controle externo, existência de órgão superior de controle administrativo, hierarquia entre as Cortes de Contas, composição, forma de seleção e nomeação dos membros dos órgãos. Além disso, inclui-se o posicionamento da Associação dos Membros dos Tribunais de Contas (ATRICON) sobre a criação do Conselho Nacional dos Tribunais de Contas.

\subsection{Modelo de Controle Externo}

Como exposto anteriormente, os modelos de controle externo no mundo são divididos basicamente em dois, quais sejam, Tribunal de Contas e AuditoriasGerais (controladorias). Historicamente, o primeiro voltava-se ao controle da formalidade da atividade administrativa, principalmente com a legalidade. Já o segundo, concentrava-se no controle gerencial com controles, desempenho, eficiência, eficácia e efetividade. Atualmente, os sistemas dos Tribunais de Contas têm desenvolvido atividades de controle envolvendo a gestão por meio das auditorias operacionais e dos indicadores de gestão.

\footnotetext{
58 BRASIL. Câmara dos Deputados. Proposta de Emenda à Constituição no 90/2007. Disponível em: <http://www.senado.gov.br/atividade/materia/detalhes.asp?p_cod_mate= 82820>. Acesso em: 02 abr. 2015.

59 BRASIL. Câmara dos Deputados. Proposta de Emenda à Constituição no 329/2013. Disponível em: <http://www.camara.gov.br/proposicoesWeb/fichadetramitacao?idProposicao= 597232>. Acesso em: 02 abr. 2015.
} 
RAMIRES, Celso Costa; ROCHA NETO, Odir Gomes da. A reforma dos Tribunais de Contas: uma revisão a partir das propostas de emendas constitucionais. Revista Eletrônica Direito e Política, Programa de Pós-Graduação Stricto Sensu em Ciência Jurídica da UNIVALI, Itajaí, v.10, n.2, $1^{\circ}$ quadrimestre de 2015. Disponível em: www.univali.br/direitoepolitica - ISSN 1980-7791.

O fator diferenciador dos dois modelos consiste no fato de os Tribunais de Contas serem órgãos colegiados, em que suas deliberações são tomadas por meio de Câmaras ou do Plenário, enquanto na Auditoria-Geral, as decisões são singulares, lavradas pelo Auditor-Geral (Controlador Geral). Em ambos, existe um corpo técnico de apoio, formados por auditores ou analistas, que subsidiam o voto dos conselheiros ou ministros, no caso dos Tribunais de Contas, ou do parecer do Auditor-Geral. O grau de autonomia do corpo técnico em relação aos membros do órgão de controle externo varia entre nulo e alta, em que o auditor possui liberdade para decidir como fiscalizar e os cargos de chefia e direção são nomeados entre os próprios participantes deste corpo técnico.

A PEC no 75/2007 propõe a autonomia entre o Corpo Deliberativo e a Auditoria de Controle Externo, como se transcreve do art. 73:

Art.73 - O Tribunal de Contas da União, compõe-se por um Corpo Deliberativo, integrado por nove Ministros, e pela Auditoria de Controle Externo, tem sede no Distrito Federal, quadro próprio de pessoal e jurisdição em todo o Território Nacional, exercendo no que couber, as atribuições previstas no art.96. ${ }^{60}$ (grifo dos autores)

A Auditoria de Controle Externo ganha autonomia em relação ao corpo deliberativo ao determinar que haverá um Auditor Geral de Controle Externo escolhido dentre os integrantes da carreira de servidores efetivos do Tribunal de Contas. Tal modelo também se estenderá aos Tribunais de Contas Estaduais e Municipais ao incluir o parágrafo primeiro no artigo 75 da CRFB/88 para estabelecer a existência do Corpo Deliberativo e da Auditoria de Controle Externo, in verbis:

$\S 1^{0}$ - As Constituições Estaduais e a Lei Orgânica do Distrito Federal disporão sobre os Tribunais de Contas respectivos, compostos por um Corpo Deliberativo, integrado por sete Conselheiros, e pela Auditoria de Controle Externo, assegurando-Ihes quanto à organização, composição e fiscalização, as mesmas garantias e prerrogativas institucionais estabelecidas nesta seção. ${ }^{61}$ (Grifo nosso).

\footnotetext{
60 BRASIL. Câmara dos Deputados. Proposta de Emenda à Constituição no 75/2007.

${ }^{61}$ BRASIL. Câmara dos Deputados. Proposta de Emenda à Constituição no 75/2007.
} 
RAMIRES, Celso Costa; ROCHA NETO, Odir Gomes da. A reforma dos Tribunais de Contas: uma revisão a partir das propostas de emendas constitucionais. Revista Eletrônica Direito e Política, Programa de Pós-Graduação Stricto Sensu em Ciência Jurídica da UNIVALI, Itajaí, v.10, n.2, $1^{\circ}$ quadrimestre de 2015. Disponível em: www.univali.br/direitoepolitica - ISSN 1980-7791.

A PEC no 90/2007, por sua vez, busca uma modificação severa no modelo de controle externo dos Tribunais de Contas no Brasil. Ao mesmo tempo que propõe a extinção dos Tribunais de Contas, pretende a criação da Auditoria-Geral, subordinada às Casas Legislativas como órgão técnico de controle externo.

A PEC no 90/2007 torna-se polêmica na medida em que prevê no seu artigo 16 a extinção dos cargos de Ministro e Conselheiro dos Tribunais de Contas, que serão colocados em disponibilidade.

O artigo 71 da CRFB/88 seria reformulado com a seguinte redação:

Art. 71. O controle externo, a cargo do Congresso Nacional, será exercido com o auxílio da Auditoria de Contas da União, órgão integrante da estrutura administrativa dessa Casa e vinculado diretamente ao seu Presidente. ${ }^{62}$

A Auditoria de Contas da União a ser criada seria chefiada pelo Auditor-Geral de Contas da União, nomeado pelo Presidente do Congresso Nacional entre auditores de contas da União, com aprovação pelo Plenário da Casa. Tais auditores pertenceriam ao quadro da Auditoria de Contas da União, por meio de concurso público exclusivamente. Inclusive, as funções de confiança e os cargos em comissão de tal órgão seriam privativos dos servidores do quadro próprio de pessoal.

Por fim, a PEC no 329/2013 ao alterar o artigo 73 da CRFB/88, prevê a separação entre as atividades deliberativas e de fiscalização e instrução, que deverão ser coordenadas por um Diretor-Geral eleito dentre os auditores de controle externo.

${ }^{62}$ BRASIL. Senado Federal. Proposta de Emenda à Constituição no 90/2007. 
RAMIRES, Celso Costa; ROCHA NETO, Odir Gomes da. A reforma dos Tribunais de Contas: uma revisão a partir das propostas de emendas constitucionais. Revista Eletrônica Direito e Política, Programa de Pós-Graduação Stricto Sensu em Ciência Jurídica da UNIVALI, Itajaí, v.10, n.2, $1^{\circ}$ quadrimestre de 2015. Disponível em: www.univali.br/direitoepolitica - ISSN 1980-7791.

\subsection{Controles administrativos dos Tribunais de Contas}

Rubens Naves, ao escrever o artigo "Quem controla o controlador", 63 expôs a sua preocupação considerando que o TCU, como órgão da Administração Pública, também deve ser fiscalizado na mesma medida que todos os demais órgãos da Administração Pública.

Tal apreensão se estendeu aos congressistas, uma vez que a PEC no 30/2007 contém a proposta da criação do Conselho Nacional dos Tribunais de Contas. O novo conselho será composto de quinze membros, com mandato de dois anos, admitida uma recondução, da seguinte forma:

I - dois Ministros do Tribunal de Contas da União, indicados pelo respectivo tribunal;

II - três Conselheiros dos Tribunais de Contas dos Estados, indicados pelos respectivos tribunais, na forma da lei;

III - um Conselheiro dos Tribunais de Contas dos Municípios, indicado pelos respectivos tribunais, na forma da lei;

IV - dois membros do Ministério Público junto ao Tribunal de Contas da União, indicados pelo respectivo Ministério Público;

V - dois membros dos Ministérios Públicos junto aos Tribunais de Contas dos Estados, indicados pelos respectivos Ministérios Públicos, na forma da lei;

VI - um membro dos Ministérios Públicos junto aos Tribunais de Contas dos Municípios, indicados pelos respectivos Ministérios Públicos, na forma da lei;

VII - dois advogados, indicados pelo Conselho Federal da Ordem dos Advogados do Brasil;

VIII - dois cidadãos de idoneidade moral e reputação ilibada, dotados de notórios conhecimentos jurídicos, contábeis, econômicos e financeiros ou de administração

\footnotetext{
${ }^{63}$ NAVES, Rubens. TCU: Quem controla o controlador? Le Monde Diplomatique - Brasil. São Paulo, p. 1-2. 05 jun. 2009. Disponível em: <http://www.diplomatique.org.br/artigo.php?id=352>. Acesso em: 28 nov. 2014.
} 
RAMIRES, Celso Costa; ROCHA NETO, Odir Gomes da. A reforma dos Tribunais de Contas: uma revisão a partir das propostas de emendas constitucionais. Revista Eletrônica Direito e Política, Programa de Pós-Graduação Stricto Sensu em Ciência Jurídica da UNIVALI, Itajaí, v.10, n.2, $1^{\circ}$ quadrimestre de 2015. Disponível em: www.univali.br/direitoepolitica - ISSN 1980-7791.

pública, indicados um pela Câmara dos Deputados e outro pelo Senado Federal. ${ }^{64}$

Tal conselho será responsável pelo: a) controle administrativo e financeiro dos Tribunais de Contas, b) controle dos deveres funcionais dos ministros, conselheiros, auditores dos Tribunais de Contas e dos membros do Ministério Público junto às Cortes de Contas, bem como dos serviços auxiliares dos Tribunais de Contas.

Por sua vez, a PEC no 329/2013 amplia explicitamente a competência do Conselho Nacional de Justiça (CNJ) para abranger a fiscalização dos deveres funcionais dos ministros, auditores substitutos de ministros, conselheiros e auditores substitutos de conselheiros, de acordo com as competências fixadas no artigo 103-B, $\S 40$, inciso III, da CRFB/88. Para tanto, acrescentar-se-á uma vaga no CNJ destinada a um Ministro ou Conselheiro de Tribunal de Contas, a ser indicado pelo Tribunal de Contas da União.

Neste ponto, em dezembro de 2013, no XXVII Congresso dos Tribunais de Contas do Brasil, a Associação dos Membros dos Tribunais de Contas do Brasil (ATRICON) aprovou a Declaração de Vitória ${ }^{65}$ com o posicionamento em prol da defesa da criação do Conselho Nacional dos Tribunais de Contas, que deverá ter competência de normatização, integração, correição e coordenação do Sistema de Tribunais de Contas.

\subsection{Composição das Cortes de Contas}

A forma atual de escolha e nomeação dos ministros e conselheiros passa por críticas que foram expostas no artigo: "A imagem dos tribunais de contas subnacionais", escrito por Rogério Bastos Arantes e outros ${ }^{66}$, após entrevistar

\footnotetext{
${ }^{64}$ BRASIL. Senado Federal. Proposta de Emenda à Constituição nº 30/2007.

${ }^{65}$ ASSOCIAÇÃO DOS MEMBROS DOS TRIBUNAIS DE CONTAS DO BRASIL. Declaração de Vitória. XXVII Congresso dos Tribunais de Contas do Brasil. Disponível em: <http://www.atricon.org.br/documentos/declaracao-de-vitoria/>. Acesso em: 11 mar. 2015.

${ }^{66}$ ARANTES, Rogério Bastos; ABRUCIO, Fernando Luiz; TEIXEIRA, Marco Antônio Carvalho. A imagem dos Tribunais de Contas subnacionais. Revista do Serviço Público, Brasília, v. 56, n. 1,
} 
RAMIRES, Celso Costa; ROCHA NETO, Odir Gomes da. A reforma dos Tribunais de Contas: uma revisão a partir das propostas de emendas constitucionais. Revista Eletrônica Direito e Política, Programa de Pós-Graduação Stricto Sensu em Ciência Jurídica da UNIVALI, Itajaí, v.10, n.2, $1^{\circ}$ quadrimestre de 2015. Disponível em: www.univali.br/direitoepolitica - ISSN 1980-7791.

919 (novecentos e dezenove) agentes públicos. O aludido artigo relata sobre a politização e falta de independência dos Tribunais de Contas como um dos problemas mais destacados. O estudo identificou três problemas dos Tribunais de Contas que foram mais realçados pelos entrevistados:

Politização do Tribunal e falta de independência;

Falta de transparência e de relação com a sociedade;

Burocratização das atividades e lentidão das respostas.

Desses, a politização e a falta de independência do Tribunal - é, sem dúvida, o que mais se destacou. A maior parte das respostas apontou esse problema como o mais grave na caracterização dos TCs subnacionais. A politização indesejável da instituição acometeria suas diversas dimensões, conformando-lhe imagem externa bastante negativa: o processo de escolha dos conselheiros, decisões políticas contrariando aspectos técnicos, ingerência externa no funcionamento do TC, ações políticas de perseguição a adversários e omissões graves diante de correligionários, da corrupção e do nepotismo. ${ }^{67}$ (Grifo nosso).

Nesta seara, os autores da PEC no $329 / 2013$ informam na justificativa que " $25 \%$ dos membros dos Tribunais de Contas estaduais não possuem a formação adequada para exercer a função" ${ }^{68}$. Sem contar que "o problema mais grave, porém, é o estreito vínculo mantido e cultivado entre muitos dos membros nomeados para essas Cortes e as forças políticas responsáveis pelas suas nomeações". 69

Por tais motivos, a PEC no 329/2013 propõe que os Tribunais de Contas dos Estados continuem a ser integrados por sete conselheiros, mas com a forma de escolha alterada, na seguinte ordem:

p.57-83, jan./mar de 2005. Trimestral. Disponível em: <http://seer.enap.gov.br/index.php/RSP/article/view/217>. Acesso em: 28 nov. 2014.

${ }^{67}$ ARANTES, Rogério Bastos; ABRUCIO, Fernando Luiz; TEIXEIRA, Marco Antônio Carvalho. A imagem dos Tribunais de Contas subnacionais. Revista do Serviço Público. p. 73.

68 BRASIL. Câmara dos Deputados. Justificativa da Proposta de Emenda à Constituição no 329/2013. Disponível em: <http://www.camara.gov.br/proposicoesWeb/fichade tramitacao?idProposicao=597232 >. Acesso em: 23 nov. 2014.

${ }^{69}$ BRASIL. Câmara dos Deputados. Justificativa da Proposta de Emenda à Constituição no $329 / 2013$. 
RAMIRES, Celso Costa; ROCHA NETO, Odir Gomes da. A reforma dos Tribunais de Contas: uma revisão a partir das propostas de emendas constitucionais. Revista Eletrônica Direito e Política, Programa de Pós-Graduação Stricto Sensu em Ciência Jurídica da UNIVALI, Itajaí, v.10, n.2, $1^{\circ}$ quadrimestre de 2015. Disponível em: www.univali.br/direitoepolitica - ISSN 1980-7791.

I. 1 (um) eleito pela classe dentre os Auditores de Controle Externo do Tribunal que tenham sido nomeados em decorrência de concurso público há pelo menos 10 anos;

II. 1 (um) eleito pela classe dentre os membros vitalícios do Ministério Público de Contas;

III. 1 (um) eleito, alternadamente, pelos conselhos profissionais das ciências previstas no art. $73, \S 10$, III, para mandato de quatro anos;

IV. 4 (quatro) eleitos pela classe dentre os Auditores Substitutos de Conselheiro vitalícios. ${ }^{70}$

Ao restringir a escolha de quatro conselheiros aos Auditores Substitutos de Conselheiro, uma dentre os Auditores de Controle Externo e uma destinada aos membros do Ministério Público de Contas, os congressistas buscam restringir a liberdade das Assembleias Legislativas e do Governador. Ao mesmo tempo, privilegiam as carreiras cujo ingresso ocorre por meio do concurso público. Já o membro proveniente dos conselhos de classe destina-se a fazer as vezes de representantes da sociedade, com mandatos de quatro anos.

Com a PEC no 75/2007, os membros passam a ter mandatos de três anos, sendo vedada a recondução para o período imediatamente subsequente. A forma de escolha também se altera para valorizar os servidores efetivos do quadro de pessoal dos órgãos de controle externo e dos membros do Ministério Público junto ao Tribunal de Contas, conforme se extrai da Proposta:

I - um terço pelo Presidente da República, com aprovação do Senado Federal, sendo dois alternadamente dentre servidores em atividade do quadro de servidores efetivos de nível superior do controle externo e membros do Ministério Público junto ao Tribunal, com 10 anos de efetivo serviço no Tribunal de Contas da União, indicados em lista tríplice mediante eleição pelos servidores efetivos da atividade fim dos Tribunais e do Ministério Público junto ao Tribunal;

II - dois terços pelo Congresso Nacional, sendo um terço dentre servidores em atividade no quadro de servidores efetivos, titulares de cargo de nível superior, com 10 anos de atividade no Tribunal de Contas da União, indicados em lista tríplice mediante eleição, na qual o colégio eleitoral será

\footnotetext{
70 BRASIL. Câmara dos Deputados. Proposta de Emenda à Constituição no 329/2013.
} 
RAMIRES, Celso Costa; ROCHA NETO, Odir Gomes da. A reforma dos Tribunais de Contas: uma revisão a partir das propostas de emendas constitucionais. Revista Eletrônica Direito e Política, Programa de Pós-Graduação Stricto Sensu em Ciência Jurídica da UNIVALI, Itajaí, v.10, n.2, $1^{\circ}$ quadrimestre de 2015. Disponível em: www.univali.br/direitoepolitica - ISSN 1980-7791.

composto pelo quadro de servidores efetivos do controle externo. ${ }^{71}$

A PEC no 15/2007, por sua vez, inova sobremaneira ao prever a realização de concurso público para a nomeação dos Ministros do Tribunal de Contas. Nesta proposta, a exoneração de tais membros, será efetuada pelo Congresso Nacional, sendo decidida a perda do cargo pela maioria absoluta dos membros de cada casa, nos casos de crime contra a administração pública, improbidade administrativa, aplicação irregular de dinheiro público, revelação de segredo do qual se apropriou em razão do cargo, lesão aos cofres públicos, dilapidação do patrimônio nacional ou corrupção. ${ }^{72}$

\subsection{Hierarquia entre as Cortes de Contas}

Como já se havia comentado anteriormente, os Tribunais de Contas não formam um sistema nacional, sendo que o Tribunal de Contas da União não seria considerado um órgão superior aos demais. Diante de tal ausência, permite-se entendimentos dissonantes sobre a legislação nacional, precipuamente nas licitações, nos limites impostos pela Lei de Responsabilidade Fiscal e nos limites constitucionais para dispêndios com saúde e educação.

A PEC no 329/2013 prevê a instituição de procedimento extraordinário de uniformização de jurisdição de contas, a ser proposto por qualquer Conselheiro ou membro do Ministério Público de Contas de qualquer Tribunal de Contas, a ser processado pelo Tribunal de Contas da União. Tal processo ocorrerá diante de decisão emitida por Tribunal de Contas, que contraria dispositivo da CRFB/88 ou de lei nacional, tendo o julgamento repercussão geral. Dessa forma, é criado mecanismo saneador das divergências entre os julgamentos das Cortes de Contas.

\footnotetext{
${ }^{71}$ BRASIL. Câmara dos Deputados. Proposta de Emenda à Constituição no 75/2007.

72 BRASIL. Senado Federal. Proposta de Emenda à Constituição no 15/2007.
} 
RAMIRES, Celso Costa; ROCHA NETO, Odir Gomes da. A reforma dos Tribunais de Contas: uma revisão a partir das propostas de emendas constitucionais. Revista Eletrônica Direito e Política, Programa de Pós-Graduação Stricto Sensu em Ciência Jurídica da UNIVALI, Itajaí, v.10, n.2, $1^{\circ}$ quadrimestre de 2015. Disponível em: www.univali.br/direitoepolitica - ISSN 1980-7791.

\section{CONSIDERAÇÕES FINAIS}

O modelo de controle externo brasileiro encontra-se em debate no Congresso Nacional desde 1996, notadamente para modificar a atuação dos Tribunais de Contas. Como muitas críticas são destinadas ao modelo adotado no Brasil, o presente artigo aprofundou-se nas diversas propostas de Emendas Constitucionais que procuram alterar as Cortes de Contas federal e subnacionais. Para tanto, selecionou-se elementos estruturantes a partir da qual se realizou a pesquisa nas Propostas Legislativas entre 2007 e 2013, quais sejam: o modelo de controle externo, controles administrativos dos Tribunais de Contas, composição das Cortes de Contas e hierarquia entre as Cortes de Contas.

Percebeu-se que as Emendas Constitucionais buscam aprimorar o modelo de Tribunais de Contas ao separar o corpo deliberativo da área técnica ou, ao contrário, propõem a extinção das Cortes de Contas, com a respectiva substituição pelo modelo de Auditoria-Geral. Outras propostas, visam à criação do Conselho Nacional dos Tribunais de Contas, como meio de aprimorar o controle dos deveres funcionais dos membros e dos servidores. Por fim, as propostas de Emendas Constitucionais selecionadas tratam da designação e exoneração dos ministros e conselheiros, partindo da opção de manutenção do status quo até a previsão de seleção por concurso público.

Não se buscou no presente trabalho exaurir a discussão sobre os Tribunais de Contas, mas sim condensar os principais pontos de debate, nas quais as propostas de Emenda à Constituição alterarão as regras do jogo processual administrativo, notadamente, as regras de composição dos órgãos responsáveis pelo controle externo.

\section{REFERÊNCIAS DAS FONTES CITADAS}

ARANTES, Rogério Bastos; ABRUCIO, Fernando Luiz; TEIXEIRA, Marco Antônio Carvalho. A imagem dos Tribunais de Contas subnacionais. Revista do Serviço Público, Brasília, v. 56, n. 1, p.57-83, jan./mar de 2005. Trimestral. Disponível 
RAMIRES, Celso Costa; ROCHA NETO, Odir Gomes da. A reforma dos Tribunais de Contas: uma revisão a partir das propostas de emendas constitucionais. Revista Eletrônica Direito e Política, Programa de Pós-Graduação Stricto Sensu em Ciência Jurídica da UNIVALI, Itajaí, v.10, n.2, $1^{\circ}$ quadrimestre de 2015. Disponível em: www.univali.br/direitoepolitica - ISSN 1980-7791.

em: <http://seer.enap.gov.br/index.php/RSP/article/view/217>. Acesso em: 11 mar. 2015.

ASSOCIAÇÃO DOS MEMBROS DOS TRIBUNAIS DE CONTAS DO BRASIL. Declaração de Vitória. XXVII Congresso dos Tribunais de Contas do Brasil. Disponível em: http://www.atricon.org.br/documentos/declaracao-de-vitoria. Acesso em: 11 mar. 2015.

BRASIL. Câmara dos Deputados. Proposta de Emenda à Constituição no 75/2007. Disponível em: <http://www.camara.gov.br/proposicoesWeb/fichade tramitacao?idProposicao=353740>. Acesso em: 02 abr. 2015.

Câmara dos Deputados. Proposta de Emenda à Constituição no

329/2013. Disponível em: <http://www.camara.gov.br/proposicoesWeb/ fichadetramitacao?idProposicao=597232 >. Acesso em: 02 abr. 2015.

. Constituição (1988). Constituição da República Federativa do

Brasil. Disponível em: <http://www.planalto.gov.br/ccivil_03/constituicao/ constituicao.htm>. Acesso em: 02 abr. 2015.

Lei no 8.443, de 16 de Julho de 1992. Lei Orgânica do TCU. Dispõe sobre a Lei Orgânica do Tribunal de Contas da União e dá outras providências. Disponível em: <http://www2.camara.gov.br/legin/fed/lei/1992/lei-8443-16-julho-1992365298-norma-pl.html>. Acesso em: 11 mar. 2015.

. Lei no 10.356 de 27 de Dezembro de 2001. Dispõe sobre o Quadro de Pessoal e o Plano de Carreira do Tribunal de Contas da União e dá outras providências. Disponível em: <http://www.planalto.gov.br/ccivil_03/leis/ LEIS_2001/L10356.htm>. Acesso em: 11 mar. 2015.

$15 / 2007$

Senado Federal. Proposta de Emenda à Constituição no <http://www.senado.leg.br/atividade/materia/detalhes.asp?

p_cod_mate $=80082>$. Acesso em: 02 abr. 2015.

30/2007.
. Senado Federal. Proposta de Emenda à Constituição
Disponível <http://www.senado.gov.br/atividade/materia/detalhes.asp?p_ cod_mate=80566> . Acesso em: 02 abr. 2015.

90/2007 - Senado Federal. Proposta de Emenda à Constituição no <http://www.senado.gov.br/atividade/materia/detalhes.asp?

p_cod_mate $=82820>$. Acesso em: 02 abr. 2015. 
RAMIRES, Celso Costa; ROCHA NETO, Odir Gomes da. A reforma dos Tribunais de Contas: uma revisão a partir das propostas de emendas constitucionais. Revista Eletrônica Direito e Política, Programa de Pós-Graduação Stricto Sensu em Ciência Jurídica da UNIVALI, Itajaí, v.10, n.2, $1^{\circ}$ quadrimestre de 2015. Disponível em: www.univali.br/direitoepolitica - ISSN 1980-7791.

BRITO, Carlos Ayres. O Regime Constitucional dos Tribunais de Contas. In: SOUZA, Alfredo José de et al. O Novo Tribunal de Contas: Órgão Protetor dos Direitos Fundamentais. Belo Horizonte: Fórum, 2004. p. 176-178.

FERNANDES, Jorge Ulisses Jacoby. Tribunais de Contas do Brasil: jurisdição e competência. $3^{a}$ ed. rev. atual. e ampl. Belo Horizonte: Fórum, 2012.

FREITAS, Cláudia. Retrospectiva - Manifestações de junho agitaram todo o país: Protestos nas ruas abrangeram os mais variados temas. Jornal do Brasil. Rio de Janeiro. 17 dez. 2013. Disponível em: <http://www.jb.com.br/retrospectiva2013/noticias/2013/12/17/retrospectiva-manifestacoes-de-junho-agitaram-todoo-pais/>. Acesso em: 09 mar. 2015.

INSTITUTO RUI BARBOSA; ASSOCIAÇÃO DOS MEMBROS DOS TRIBUNAIS DE CONTAS DO BRASIL (Coord.) Normas de Auditoria Governamental - NAGs: Aplicáveis ao Controle Externo Brasileiro. 2010. Disponível em: <http://www.controlepublico.org.br/files/Proposta-de-Anteprojeto-NAGs_2411.pdf >. Acesso em: 18 fev. 2015.

JAPAN. Board of Audit of Japan. History of the Board. Disponível em: <http://www.jbaudit.go.jp/english/jbaudit/history.html>. Acesso em: 12 mar. 2015.

http://www.jbaudit.go.jp/english/jbaudit/organization.html>. Acesso em: 12 mar. 2015.

MELLO, Celso Antônio Bandeira de. O enquadramento constitucional do Tribunal de Contas. In: FREITAS, Ney José de (Org.). Tribunais de Contas: Aspectos polêmicos: estudos em homenagem ao Conselheiro João Féder. Belo Horizonte: Fórum, 2009.

MORENO, Ana Carolina. Resultado das manifestações de junho: Veja quais foram as principais demandas, a linha do tempo dos protestos e como os poderes reagiram a eles. Portal de notícias G1. Edição: Leo Aragão (Arte) e Gustavo Miller (Conteúdo). Design: Dalton Soares, Daniel Roda e Elvis Martuchelli. Desenvolvedores: Rafael Soares e Thiago Bittencourt. Rio de Janeiro, 28 jun. 2013. Disponível em: <http://g1.globo.com/brasil/linha-tempo-manifestacoes2013/platb/>. Acesso em: 09 mar. 2015.

NAGEL, José. A fisionomia distorcida do controle externo. Revista TCU. Brasília, v. 31, n. 86, out/dez 2000.

NAVES, Rubens. TCU: Quem controla o controlador? Le Monde Diplomatique - Brasil. São Paulo, p. 1-2. 05 jun. 2009. Disponível em: <http://www.diplomatique.org.br/artigo.php?id=352>. Acesso em: 11 mar. 2015. 
RAMIRES, Celso Costa; ROCHA NETO, Odir Gomes da. A reforma dos Tribunais de Contas: uma revisão a partir das propostas de emendas constitucionais. Revista Eletrônica Direito e Política, Programa de Pós-Graduação Stricto Sensu em Ciência Jurídica da UNIVALI, Itajaí, v.10, n.2, $1^{\circ}$ quadrimestre de 2015. Disponível em: www.univali.br/direitoepolitica - ISSN 1980-7791.

OLIVEIRA, Regis Fernandes de. Manual de direito financeiro. 3. ed. São Paulo: Revista dos Tribunais, 2007.

Organización Internacional de las Entidades Fiscalizadoras Superiores (INTOSAI). Declaración de Lima sobre las Líneas Básicas de la Fiscalización. Disponível em: <http://www.intosai.org/fileadmin/downloads /downloads/4_documents/publications/span_publications/S_Lima_Mexico_2013. pdf >. Acesso em: 11 mar. 2015.

PASCOAL, Valdecir Fernandes. Direito financeiro e controle externo: teoria, jurisprudência e $\mathbf{4 0 0}$ questões. Rio de Janeiro: Elsevier, 2008.

PISARELLO, Gerardo. Los derechos sociales y sus garantías. Madrid: Trotta, 2007.

REPÚBLICA POPULAR DA CHINA. National Audit Office of the People's Republic of China. About us. Legal status. Auditing System. Disponível em: <http://www.cnao.gov.cn/main/AboutUs_ArtID_726.htm>. Acesso em: 12 mar. 2015.

RIBAS JUNIOR. Salomão. Uma viagem a Hessen: a função dos Tribunais de Contas: as realidades no Brasil e na Alemanha. Tribunal de Contas do Estado de Santa Catarina: Florianópolis, 1996.

ROCHA, Carlos Alexandre Amorim. O Modelo de Controle Externo Exercido pelos Tribunais de Contas e as Proposições Legislativas sobre o Tema. p. 8. Disponível em: <http://www2.senado.leg.br/bdsf/item/id/156>. Acesso em 23 nov. 2014.

ROCHA NETO, Odir Gomes da. Adesão (Carona) à ata de registro de preços na visão dos tribunais de contas. Monografia (Especialização em Estudos Estratégicos em Administração Pública). Universidade do Estado de Santa Catarina - UDESC. Florianópolis, 2011. Disponível em: <http://www.enabrasil.sc.gov.br/assets/anexos/pdf/de61f8daaa31659adcb3765 1d356abce2012_07_18_22_08_24.pdf>. Acesso em: 09 mar. 2015.

UNIÃO EUROPEIA. Tribunal de Contas Europeu. Governação. Disponível em: <http://www.eca.europa.eu/pt/Pages/Structure.aspx>. Acesso em: 12 mar. 2015.

UNITED STATES. General Accouting Office. Disponível em: <http://www.gao.gov/about/cgprocess.html>. Acesso em: 12 mar. 2015.

IOCKEN, Sabrina Nunes. Em busca da legitimidade da judicatura de contas: O modelo constitucional. In: LIMA, Luiz Henrique (Coord.). Tribunais de Contas: Temas polêmicos na visão de ministros e conselheiros substitutos. Belo Horizonte: Fórum, 2014. p. 203-204. 
RAMIRES, Celso Costa; ROCHA NETO, Odir Gomes da. A reforma dos Tribunais de Contas: uma revisão a partir das propostas de emendas constitucionais. Revista Eletrônica Direito e Política, Programa de Pós-Graduação Stricto Sensu em Ciência Jurídica da UNIVALI, Itajaí, v.10, n.2, $1^{\circ}$ quadrimestre de 2015. Disponível em: www.univali.br/direitoepolitica - ISSN 1980-7791.

Políticas Públicas: 0 controle do tribunal de contas. Florianópolis: conceito Editorial, 2014, p. 47.

Submetido em: Março/2015

Aprovado em: Abril/2015 